\title{
大正時代の靖国神社地改修における長岡安平の設計案とその実現
}

\section{The Repair Plan and Realization of the Yasukuni Jinja Shrine by Yasuhei Nagaoka in the Taisho Era}

浦㠃 真一*

Shinichi URASAKI

\begin{abstract}
This study was intended to examine the repair plan for the Yasukuni Jinja shrine and its realization, which was designed by Yasuhei Nagaoka. The Yasukuni shrine's repair process in the Taisho Era inspected by utilizing the drawings that Nagaoka possessed. The extent of Nagaoka's design policy in the planning was thereby clarified. The design aimed at bolstering the sacredness of the Yasukuni shrine. However, this realization was not easy; the construction was altered and divided repeatedly, and there were many areas that did not follow the original plan. The problematic factors include financial limitations and differences in understanding Nagaoka's plan. Only the north-south road's construction followed the original plan. There were changes in the western part of the former riding ground. Greater solemnity for the Yasukuni shrine was accomplished partially in the former riding ground, as the approach with the lanterns were repaired and the view of the two Torii gates was made more magnificent than originally planned.
\end{abstract}

Keywords: Yasukuni Jinja shrine, repair plan, Yasuhei Nagaoka, Taisho Era キーワード：靖国神社, 改修設計, 長岡安平, 大正時代

\section{1. はじめに}

靖国神社は明治2（1869）年，戊辰戦争以来の殉死者慰霊のた めに創建され，以後戦役の殉死者を祭神として合祀を繰り返しな がら現在まで祭祀されてきた。現在では東京のサクラ開花の標本 木があることから春には親しまれる一方で, 政治的な沮上に上る ことも少なくない。

創建当初，招魂社と呼ばれていた頃には殉死者を慰霊する場と して国家的な祭祀がおこなわれると同時に，その祭礼は市民の楽 しみともなっていた。佐藤は，創建当初の靖国神社は，東京の住 人たちにとって賑やかな祝祭の場だったと指摘し, 明治6 (1873) 年の太政官布達によって公園化された寺社地と同様の感覚で受け 入れられていたとしている1)。

しかし太政官布達によって寺社地が公園として扱われたことに 続き，東京市区改正設計が多くの公園を神社に求めたことについ ては，批判の声が上がることとなった。河村によれば，神社の公 園化についての再検討は明治 30 (1897）年頃に広がりをみせ, やがて大正 8（1919）年頃から造園学, 建築学において神社地設 計や神社の運営方法の提唱へとつながっていくこととなる ${ }^{2}$ 。 この風潮は靖国神社も例外ではなく，造園家小沢圭次郎は明治 26 （1893）年に発表した「公園論」により，市区改正設計に対し て神社の公園化を強く批判し，靖国神社を敷地とする富士見町公 園についても「欧米ノ各国中二，其公園内二於テ，一歳両次ノ大 祭典习執行シ，海陸兵隊等整列参拝习為シ，園地過半习挙テ，大 競馬場习設置シ，競馬遊等ヨ為ス所八，我未夕嘗テ之有ル事习聞 カサルナリ，実二奇妙ノ公園モ有レハ在ルモノナリ」3)と論じて いる。

東京府や東京市で公園行政を牽引してきた長岡安平も「神境神 苑と普通人の行楽地たる公園とを混同して併設しようと言ふのは 思はざるの甚だしきものではありますまいか」4)と述べている。 このような状況下，それまで一部施設の整備を中心として境内を 充実させてきた靖国神社に, 大正 3 (1914）年頃から神社地の改
修計画が持ち上がる。これにあたり，靖国神社地改修の必要性を 献言した長岡安平がその改修設計を担当するに至った 5)。長岡安 平はわが国の公園黎明期に全国の公園設計を手掛けた造園家で, 設計にかかわった事業は生涯に187 ヶ所にのぼる6)。

長岡の所持した設計図書等による長岡安平史料群 7には，靖国 神社地の設計図を含む関連図 8 点が残されている。これらは当時 の靖国神社地に求められた姿と, 設計完成に至る過程を知ること ができるとともに，これまでに明らかにされていない長岡の神社 地像を知る貴重な史料である。本論はこれらの図を中心に大正時 代初期に手がけられた神社地改修の経緯と, 設計者長岡安平と靖 国神社宮司賀茂百樹が目指した神社地像とその実現について明ら かにすることを目的とする。

対象と寸る図は表 - 1 に掲げた 8 枚で, 印刷された図 2 枚と手 書きによる図 6 枚からなる。本論ではまず当該年代の靖国神社地 に関わる事歴を整理し，これらの図相互の関係を明らかにする。 そのうえで，当時の行政資料，新聞記事等とともに考察し，設計 の経緯，目標像，実現の経過を検証する。

なお, 本論では原典の引用部分を除き，「靖国神社境内改良設計 図」が対象とする区域を示すときには「境内」(図 - 3 参照), 「靖 国神社旧馬場改良設計図」が対象とする区域を示すときには「旧 馬場」(図 - 4 参照), これら二つを総称するときには「靖国神社

\section{表 - 1 長岡安平史料群所収の靖国神社関連図}

\begin{tabular}{|l|l|l|}
\hline 史料番号 & \multicolumn{1}{|c|}{ 史料名 } & \multicolumn{1}{|c|}{ 略称 } \\
\hline ny0633 & 靖国神社境内平面図 (計画下図) & 参道計画図 a \\
ny0634 & 靖国神社境内図 & 境内図 \\
ny0635 & 靖国神社境内改良設計図 & 境内設計図 \\
ny0636 & 靖国神社参拝案内図及注意書 & 案内図 \\
ny0637 & 靖国神社境内計画下図 & 計画下図 \\
ny0638 & 靖国神社旧馬場改良計画図 & 旧馬場設計図 \\
ny0747 & 靖国神社参道計画図 & 参道計画図 b \\
ny0753 & 靖国神社参道計画図 & 参道計画図 $~$ \\
\hline
\end{tabular}

*株式会社公園マネジメント研究所 
地」または「神社地」と呼ぶこととする。また牛ヶ淵付属地につ いては「牛ヶ淵付属地」または「付属地」とする (図 - 1 参照)。

\section{2. 神社地の変遷}

靖国神社地は，明治 2（1869）年に招魂社創設の運びとなり, 当時軍務官副知官事であった大村益次郎らによりいくつかの候補 地の中から，宮城の北西に隣接し高燥の良地である田安台（九段 坂上）が選ばれた（表 - 2)。同年仮社殿にて創建されるが，翌 3 年には一部区域を減じ，明治5（1872）年に新正殿が竣工し遷宮 となった。その後明治11（1878）年には牛ヶ淵付属地を取得し, 翌 12 年別格官幣社に列格, 名称を靖国神社と改められる。明治 2 年の創建時の設計書にはすでに「神苑」の記載があったとされ， 明治 14 (1881）年に遊就館が建設される頃までは 4 ケ所の池泉 を有したが，遊就館の建設と増築によって境内も姿を変えた。

靖国神社地の性格と形状に大きな影響をあたえたのが，東京市 区改正設計の公園計画と市街鉄道の敷設である。まず明治 22 （1889）年の東京市区改正設計により, 靖国神社とその付属地で ある牛ヶ淵の計 38,707 坪余りが富士見町公園として指定された 8)。靖国神社地はここで神社地としてだけではなく，太政官布達 による深川公園, 愛宕公園, 麦鲆町公園などと同じように公園とし ての性格を与えられることとなった。牛ヶ淵付属地は明治 32 (1899)年に牛ヶ淵公園の名称で開園する伺いが出されている99。 しかしその後, 明治 36 (1903) 年の東京市区改正新設計では, 牛ヶ淵付属地は公園計画から外れ，富士見町公園は境内および旧

\section{表 - 2 明治・大正時代の靖国神社地事歴年表}

\begin{tabular}{|c|c|c|}
\hline \multicolumn{2}{|c|}{ 年月日 } & 項 \\
\hline M2. & 6.28 & 招魂社、仮社殿で創建 \\
\hline M3. & 11 & 境内一部売却 \\
\hline M5. & 5. 7 & 新正殿遷宮 \\
\hline M11. & 6 & 牛ヶ淵附属地買収 \\
\hline \multirow[t]{2}{*}{ M12. } & 5. 6 & 遊就館起工 \\
\hline & 6. 4 & 靖国神社に改称、別格官幣社列格 \\
\hline M14. & 5. 4 & 遊就館竣工 \\
\hline \multirow[t]{2}{*}{ M2O. } & 4.27 & 遊就館改築竣工 (第一次) \\
\hline & 12 & 大鳥居 (現 第二鳥居 ) 竣工 \\
\hline \multicolumn{2}{|l|}{ M22 } & 東京市区改正設計 \\
\hline M26. & 2 & 大村益次郎銅像竣工 \\
\hline M32. & 2. 5 & 牛ヶ淵公園開園伺い \\
\hline \multirow[t]{2}{*}{ M34. } & 9. 8 & 競馬場廃止 \\
\hline & 10. 5 & 拝殿竣工 \\
\hline \multirow[t]{2}{*}{ M36. } & 3.31 & 東京市区改正新設計 \\
\hline & 10.14 & 能楽堂芝公園より移設竣工 \\
\hline \multirow[t]{2}{*}{ M37. } & 1. 9 & 相撲場改修起工 \\
\hline & 9.15 & 神池改修 \\
\hline M38. & 4 & 市街鉄道用地譲渡 \\
\hline M39. & 2.22 & 国光館移築竣工 \\
\hline \multirow[t]{2}{*}{ M40. } & 3.11 & 市区改正道路用地、東京市へ還付・鉄道用地追加譲渡 \\
\hline & 4.25 & 遊就館改築起工 \\
\hline M41. & 9.24 & 遊就館拡張竣工 (第二次) • 社務所庭園改修 \\
\hline M42. & 8.21 & 旧馬場敷き均し・排水工事申請 \\
\hline T3. & 1.10 & 神苑改造の議起こる (東京朝日新聞) \\
\hline \multirow[t]{3}{*}{ T4. } & 2. 2 & 神苑改造図面付記事 ( 東京朝日新聞) \\
\hline & 8.27 & 神苑の大改造記事 ( 読売新聞 ) \\
\hline & 9.30 & 拝殿から大鳥居敷石工事竣工 \\
\hline \multirow[t]{4}{*}{ T6. } & 1.31 & 招魂社道路・内苑拡張記事 (東京朝日・読売) \\
\hline & 3. 2 & 旧馬場内改築追加・道路付替其他工事申請 \\
\hline & 3.30 & 新内苑成る記事 (読売新聞) \\
\hline & 5.18 & 参道改修其他工事竣工報告 \\
\hline T7. & 10.21 & 参集所竣工 \\
\hline T10. & 6. 8 & 第一鳥居竣工 \\
\hline T12. & 9. 1 & 関東大震災により拝殿、遊就館等に甚大な被害 \\
\hline
\end{tabular}

【明治期】賀茂百樹編 (1911) : 靖国神社誌: 靖国神社, 【大正期】靖国神社 (1987) : 靖国神社百年史事歴年表より抽出。ただし，本文中に特に出典を 示したものを除く。年月星中のは明治、丁は大正を示导。
馬場の区域のみとなり，面積は約 27,500 坪に減少した ${ }^{10)}$ 。当時 靖国神社を管轄していた陸軍省としては, 牛ヶ淵付属地は非常時 の社地代替地としてや諸興行のため ${ }^{11)}$, あるいは火災時の避難地 や同地利用により収益を得るための地という目的があり，公園と なってはその目的を達するための代案も得る見込みがないため 12), 設計変更を機に公園地から除外したい意向があった。東京市 区改正新設計時の公園敷地図とされる富士見町公園地籍図 13)に よれば，牛ヶ淵付属地が公園区域から除外されていることが確認 できる。一方，市街鉄道の拡張によっても靖国神社地は影響を受 けることとなり，明治 38 （1905）年 4 月には神社地南側を鉄道 敷地として減じ，明治40（1907）年に再び区域を減じた。

神社地施設に目を転じれば，明治 20 (1887) 年と明治 40 年に それぞれ遊就館の増築工事が竣工し，明治 34（1901）年には馬 場の廃止と拝殿竣工，明治 $36 （ 1903 ）$ 年能楽堂移築竣工，明治 37 年相撲場起工，神苑改修といったことが続く。明治 40 年まで は靖国神社にとって, 日露戦争の戦利品等収蔵のため遊就館が増 築され, 能楽堂や相撲場の整備など境内が充実される一方で, 都 市化による神社地の減少も進んだ時代であった。

そんな中，大正 3 （1914）年に神社地改修が議論されるように なる。それまでも旧馬場については修理がおこなわれていたが， ここにきて大規模な改修が計画されるようになった。その心境を 長岡は「大祭の時に合祀となつた遺族其他の参帱者等は勅使が来 たりして一層有難さを感じた時に華表の前でドンガン遣つて居ら れては有難味が薄くなつて了ふであらう」14) と述へ，宮司賀茂百 樹が「成るべく厳肃なもの神聖なものとさせなければならぬ」15) と支持している。しかし長岡の設計案はそのままには実施される ことなく, 数度に分けて工事が実施され, 大正 6 (1917) 年にな ってようやく「神苑」が新しくなったことが報じられた ${ }^{16) 。 ま た ~}$ この間の工事は長岡案との関係の上で論じられておらず，関係性 は明確ではない。そこで長岡による神社地改修設計の詳細と, そ の実現についての検証のため, 長岡安平史料群による設計関連図 を詳しくみていくこととする。

\section{3. 長岡安平が所持した設計関連図 \\ (1) 印刷図}

まず印刷された 2 枚の図である「靖国神社境内図」(図 - 1 , 以 下，「境内図」）と「靖国神社参拝案内図及注意書」(図 - 2, 以下, 「案内図」）について年代を検討する。この 2 枚の図を比較する と，市街鉄道軌道と遊就館に顕著な差異が認められる。

「境内図」では，市街鉄道軌道が神社南西から神社地に沿って 敷かれ，旧馬場の途中で南へ折れている。これに対し「案内図」 は, 牛ヶ淵付属地から九段坂に沿って敷かれた軌道と, 南西から の軌道が合流する。また，「境内図」の遊就館が南から東への L 字形であるのに対し,「案内図」では西側と北側に拡張され方形と なっていることがわかる。

市街鉄道が靖国神社から神社地の一部割譲を受けたのは明治 38 (1905) 年 4 月であり, 同 10 月には工事残土の扱いについて の東京市と陸軍省とのやり取りが記録されており，工事が完了し ていたことが窺える 17)。明治 40（1907）年に軌道の延伸のため 再び区域を減じたことは既述のとおりであるが，これに先立ち牛 ケ淵付属地にあった国光館が軌道の支障となることから，東京市 街鉄道より移築の許可願いが出された ${ }^{18)}$ 。この移築は明治 39 （1906）年 2 月に竣工したが，許可願いと「境内図」を比較する と国光館の位置から移築後の図であることがわかる。また，遊就 館の第二次増築は明治 40 年 4 月に起工し, 同 41 年 9 月に竣工し ている。さらに「神社前道路付替其他設計平面図」および「参道 改修其他ノ工事竣工ノ件報告」19)から大正 6 (1917）年 5 月には 旧馬場西側に南北に通寸道路が建設されており, 大正 10 (1921) 


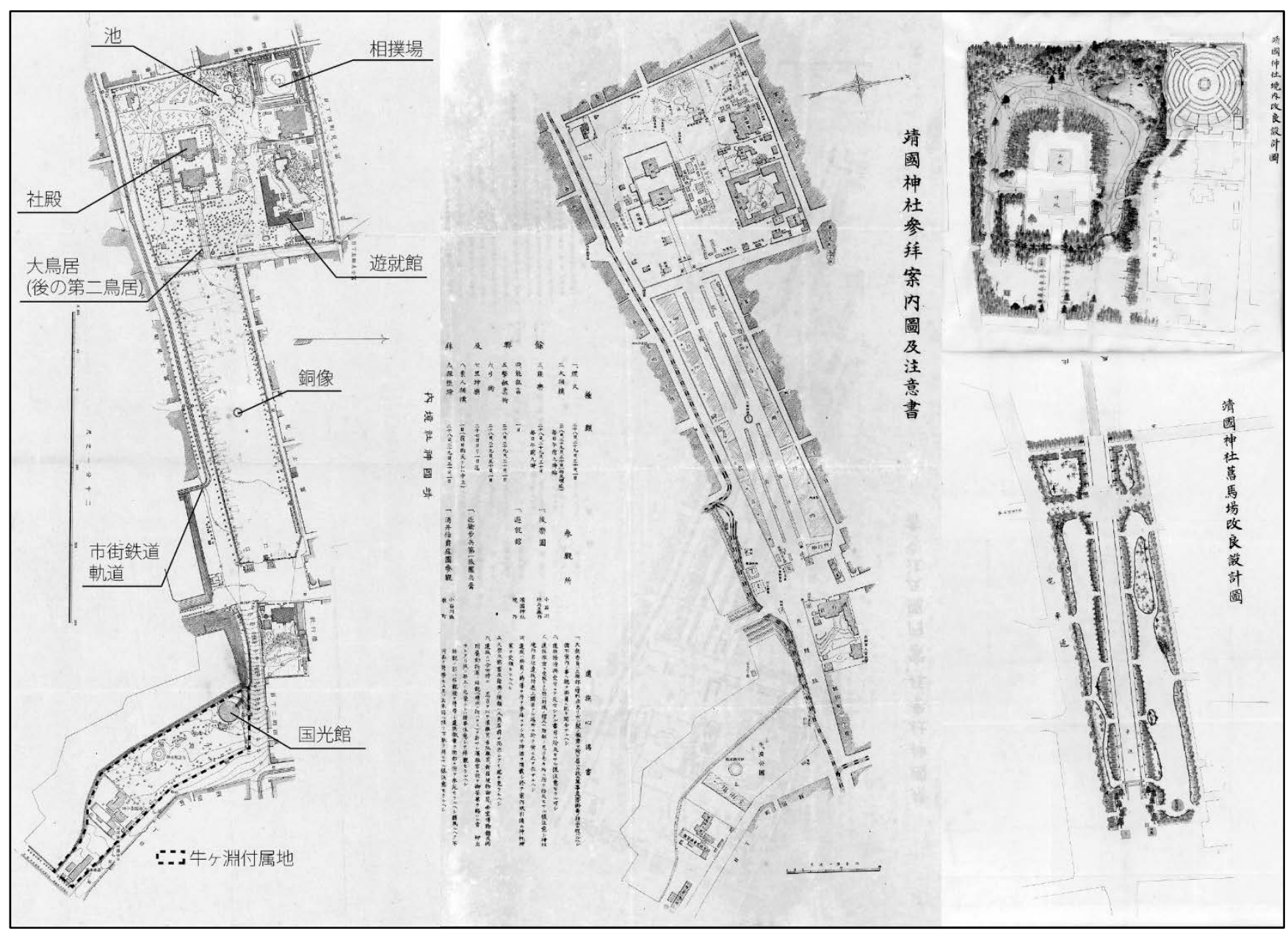

図 - 1 境内図[筆者加筆 $]$ （左） 図 - 2 案内図[部分]（中央）

図 - 3 境内設計図（右上） 図 - 4 旧馬場設計図（右下）

年には第一鳥居が竣工 ${ }^{20)}$ するが,「案内図」にはこれらが確認で きない。このことから「境内図」は明治 39 年 2 月から同 40 年 4 月までの靖国神社地を表した図であり，「案内図」は明治 41 年 9 月から大正 6 年 5 月までのそれであることがわかる。

続けて「案内図」についてみていく。これは赤黒 2 色で刷られ た印刷物で，仮設部分が赤で記入され，遺族心得書とされる箇条 書きの諸注意の内容から，祭神となった殉死者の遺族に供する， 大祭参列時の案内図であることがわかる。例えば心得書には「大 祭次第書及余興ノ種類八大鳥居前二掲示シアリ一後略」とあるこ とから大祭時であることがわかり，「三. 遺族微章习受取リタル時 八习习織ノ襟又八胸部ノ見エ易キ所二附ケ一後略」といった特に遺 族に向けた案内が示されている。「余興及拝観」覧には二十七日か ら一日のうちの 1 日あるいはこの期間の日付があり, 動物園の扯 観日には「四月二十八日ヨリ五月一日マテ」とあることから大祭 の日程は 4 月 27 日から 5 月 1 日までの 5 日間であったことが窥 える。当時，靖国神社の大祭日は 4 月 30 日と 10 月 23 日であつ た 21)ため, 官報から靖国神社臨時大祭次第を照査すると, 先述の 期間内に大正 4 (1915) 年の夕該当 22) 寸る。このことから「案内 図」は，大正 4 年 4 月 27 日から 5 月 1 日の臨時大祭時の，祭神 となった殉死者の遺族への配布のためのものであることが明らか である。

\section{(2) 手書き図}

次に手書きによる設計図をみると，着色され標題の付された設 計図 2 枚と, 鉛筆による下図 4 枚である。設計図はそれぞれ境内 と旧馬場を個別に描き，下図は神社地 1 枚と旧馬場 3 枚である。 着色された設計図である「靖国神社境内改良設計図」(図 - 3, 以 下，「境内設計図」）および「靖国神社旧馬場改良設計図」(図 - 4,

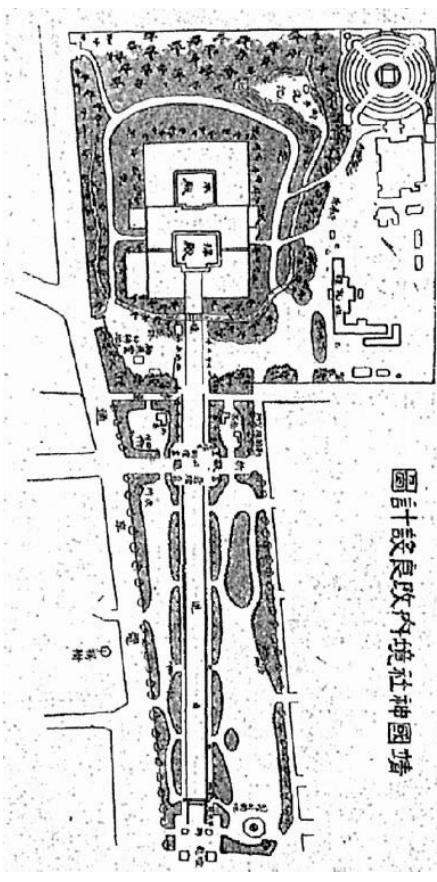

図 - 5 公表図 (左)

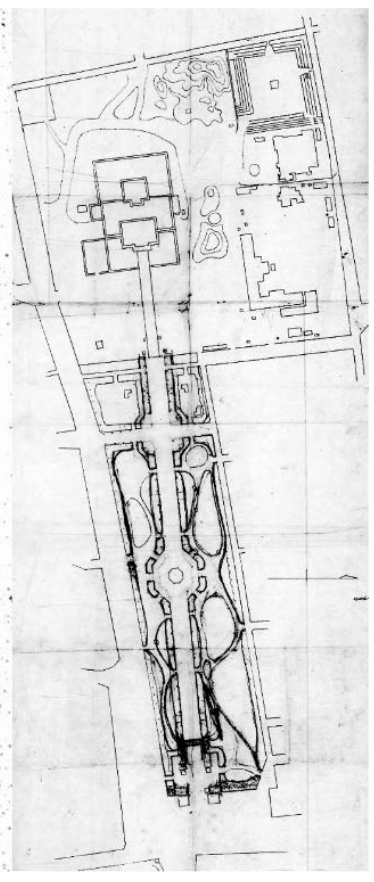

図 - 6 計画下図（右）

以下，「旧馬場設計図」）は，大正 4 年の新聞に掲載された「靖国 神社境内改良設計図」 23)（図-5, 以下,「公表図」）と比較すると, 表現の簡略化はあるが計画は概ね一致する。よってこの 2 枚の設 計図が確定案であると考えられる。 
「靖国神社境内計画下図」（図－6，以下，「計画下図」）は，手 書き図では唯一境内と旧馬場の両方を含む神社地全体の図である。 本図の境内は黒の線描図で，施設配置や園路形状の共通性と遊就 館の形状から「境内図」を原図としたことがわかる。同様に「境 内設計図」も施設配置と遊就館の形状が共通で，「境内図」および 「計画下図」にみられる園路に着色された計画が重ねられており， 両図に基づくものであると考えられる。

一方で「計画下図」の旧馬場は黒赤 2 色の計画線が書き込まれ ている。この他，「旧馬場設計図」と「靖国神社境内平面図（計画

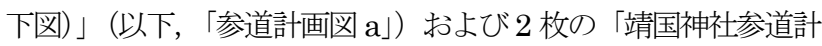
画図」（以下，それぞれ「参道計画図 $\mathrm{b} 」$,「参道計画図 $\mathrm{c}\rfloor$ ) の計 5 枚が旧馬場を対象としている。参道の動線はすべての図が直線で, 旧馬場敷地に対して東南から西北へと斜めに計画されている。境 内図」には参道は描か冯ていないが，東南と西北に出入口が確認 でき，明治42（1909）年の旧馬場敷き均し時の設計図 24)や，「案 内図」にみられる大祭時の旧馬場の仮設の使用形状から，それま での利用形態に従ったものであることがわかる。また，「参道計画 図 c」を除く 4 枚には, 旧馬場西寄りに南北に通路が通されてい る。それぞれの図にはいくつかの特徵がみられ，主要な要素によ り比較すると表 - 3 のようになる。

「計画下図」は旧馬場の中ほどの銅像の敷地と，それを回って 広げられた参道およびそれに沿う植栽帯が設けられている。参道 計画図 a」は「計画下図」と同様の参道形状で, 南北通路の境内 側には参道中央に植栽地が設けられている。また，参道東南側入 口に鳥居を描いた痕跡を確認できるが，消去されている。「参道計 画図 b」は形状から「計画下図」を書き写したものであると推察 される。「参道計画図 $\mathrm{c} 」$ は西寄りの新設南北通路が無く, 境内と 旧馬場の間を通る道路に太鼓橋様の橋が設けられている。東南側 入口は南から入り，一旦広場となって西北へ折れ参道となる。

長岡の設計関連図は以上のような図面群で構成されており, 次
項では長岡の意図と設計への反映を考察する。

\section{4. 長岡安平の意図と設計への反映}

先述のとおり東京市区改正設計を受けた神社の公園化について の再検討が広がる中，明治 44 (1911）年には長岡も新聞記事に おいて神社と公園について持論を語り，靖国神社に対する意見も 次のように述べている。

靖国神社の境内の如き多数の桜樹を栽总, 裏手には箱庭の 如き小細工的庭園を設け只々陽気にして児女の喜ぶが如きを 主とせる感あり，公園としては之でもよいが国家殉難の英霊 を祀れる社殿に対しては其境地は最も森厳幽遂に所謂神々し く自ら人の気を引緊めるやうでなければならぬ 25$)$

靖国神社地改修がいよいよ動き出した大正 3 （1914）年 1 月に は，再び以下のように改修の必要性を論じており，その内容はさ らに熱を帯びた印象を受ける。

九段の辺りを逍遥する者は彼の靖国神社の周囲及境内が余 りに俗塵に塗れて居るに気付くであらう，之に参拝する者は 社殿の荘厳と幾多の神霊との為め自から敬虔の念の生ずるも のありとは云へ顧みれば忽ち身塵罣中にあるの心地がして何 となく物足らぬ思ひを感ずるであらう，是れ何が故であるか と云へば同神社の神苑が余りに俗受け専門的に出来上がつて 居るからである，あれは何う考えても勇敢なる帝国の軍人を

\section{表 - 3 旧馬場手書き図の比較}

\begin{tabular}{|c|c|c|c|c|}
\hline 主な要素 & 西側南北通路 & 銅像 & 第一鳥居 & 参道形状 \\
\hline 旧馬場設計図 & 有 & 北東 & 有 & 直線 \\
\hline 計画下図 & 有 & 中央 & 有 & 直線 \\
\hline 参道計画図 a & 有 & 中央 & 有 & 直線 / 西奇中央植栽 \\
\hline 参道計画図 b & 有 & 中央 & 消去の痕跡 & 直線 \\
\hline 参道計画図 C & 無 & 北東 & 有 & $\begin{array}{c}\text { 南から入り西へ直線 / } \\
\text { 境内との境に橋 }\end{array}$ \\
\hline
\end{tabular}

表 - 4 新聞紙上に公開された靖国神社地改修の設計方針と理由・意図

\begin{tabular}{|c|c|c|c|}
\hline \multicolumn{2}{|r|}{ 対象 } & 設計方針 & 理由・意図 \\
\hline \multicolumn{4}{|c|}{ 設計前（大正 3 年 1 月 10 日，同 2 月 22 日，同 3 月 4 日記事） } \\
\hline \multirow[t]{3}{*}{ 神社地 } & 樹木 & $\begin{array}{l}\text { ・サクラ,ウメを撤去しヒノキ,スギ,マキ等の針葉樹 } \\
\text { 緑樹を植栽する }\end{array}$ & $\begin{array}{l}\cdot \text { •サクラ・ウメ・高価，珍奇な樹木は神社に不相応 } \\
\text { • 将来蓼蒼とした喬木林を形成する }\end{array}$ \\
\hline & 大鳥居 & •九段坂上入口に移設する & ·広場改造のため \\
\hline & 参道 & $\begin{array}{l}\text { • 入口から社殿まで一直線の石敷舗道とし,左右をヒ } \\
\text { ノキ並木とす } \\
\text { •外周樹木と並木の間に空地を設ける }\end{array}$ & ・ただ広く雨天・乾燥時の状況不良 \\
\hline \multirow[t]{4}{*}{ 境内 } & 池 & ・保存なら青苔が石をおおうようにする & \\
\hline & 道路・裏門 & ・通り抜けの道路を閉ざし，裏門は廃止する & •不体裁な境内の通行を禁じる \\
\hline & 新聞縦覧所など & •廃止する & \\
\hline & 鳥居 & •大鳥居の跡に小さい鳥居を設置する & \\
\hline \multirow[t]{2}{*}{ 旧馬場 } & 南北道路 & •二三間程掘下げ，に相応な意匠の橋を架ける & ·車馬の通行が頻繁でも神社から見えないように \\
\hline & 銅像 & ・移転する & ·入口から神殿までの一直線の参道に支障がある \\
\hline 他 & 興行 & $\begin{array}{l}\text { ・牛ヶ淵に移動し，露店商人のみ境内もしくは傍らの } \\
\text { 道路に出店を許す }\end{array}$ & $\begin{array}{c}\text { •大祭時参拝者等が勅使などで一層有難さを感じた } \\
\text { 時に鳥居の前が騒がしくては有難味が薄くなる }\end{array}$ \\
\hline \multicolumn{4}{|c|}{ 設計公開時（大正 4 年 2月 2 日記事） } \\
\hline \multirow[t]{3}{*}{ 神社地 } & 樹木 & 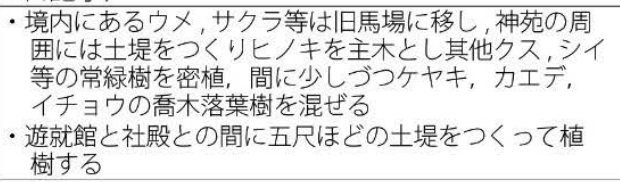 & $\begin{array}{l}\text { ・俗寰との隔壁とする } \\
\text { ・神社に近づく者が森厳の気に打たれて謹肃な心持 } \\
\text { を持つように } \\
\text { ・古風の建築である社殿と西洋風の遊就館とが一時 } \\
\text { に見えないように }\end{array}$ \\
\hline & 大鳥居 & ・旧馬場入口に移設する & \\
\hline & 参道 & $\begin{array}{c}\text { •入口から拝殿の間に十二間（車道八間歩道二間づつ） } \\
\text { の参道を設置し，左右をヒノキ並木とする }\end{array}$ & \\
\hline \multirow[t]{3}{*}{ 境内 } & 池 & $\begin{array}{l}\text { •形態は全く改造し,ハスなど淋し味のある水草を植え， } \\
\text { 現在の大華表の脇へ巾一間程の溝渠を掘り神苑を一周 } \\
\text { させて入口には古風の橋を架する }\end{array}$ & •庭園風の池だから \\
\hline & 施設 & ・神楽殿は移設し相撲場は円形のコンクリート造とする & \\
\hline & 南門及び裏門 & ・平素は閉鎖する & \\
\hline \multirow[t]{2}{*}{ 旧馬場 } & 旧馬場 & $\begin{array}{l}\text { •制札や灯籠等は旧馬場に配置し，四阿，茶屋，便所等 } \\
\text { を数箇所に設ける }\end{array}$ & \\
\hline & 銅像 & •東北端消防分署の前に南面して立てる & ·真直な道路を作るに都合が悪い \\
\hline
\end{tabular}


合祀する別格官幣社の神苑とは思われぬ寧ろ一寸した富豪の 庭園かさもなければ下手な公園である ${ }^{26)}$

その後，同年 2 月， 3 月と改修関連記事が掲載されている。こ れらの記事には長岡の改修設計への方針が記されており，こうし た検討を経て最終案として「境内設計図」および「旧馬場設計図」 が長岡により作成された。この図は「公表図」として簡略化され， 大正 4 （1915）年 2 月に新聞紙上に公表されている。これらの記 事に記された設計方針とその理由, 意図を抽出分類すると表 - $4^{27}$ のとおりである。

ここに示された設計は樹木, 通路, 池, 鳥居, 銅像, 付属施設, 利用に関わるものに大別される。樹木は花木を撤去し針葉樹を中 心とした常緑樹を密植し，旧馬場から社殿にかけて一直線の石敷 きの参道を設け，境内をみだりに通行させないよう門を閉じるこ ととしている。また鳥居や銅像のほか付属施設は必要に応じて改 修，移設，撤去が計画されている。さらに指示は物的な変更に止 まらず，興行や露占の取り扱いにもおよんでいる。これらはどれ も大きな変更を伴うもので，同年 8 月の新聞でも「幾んど原形を 留めざる様に大改造を加ふる」28) と評されたが，その目指寸とこ ろはただ一点, 神社としての荘厳さを創出するためということに 尽きる。これは神社側の希望でもあり，当時の賀茂宮司は「此の

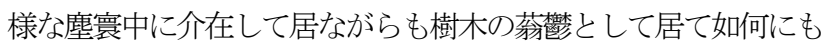
神聖な場処らしい気分を一般参帱者に持たしむる様になれば」29) と期待を寄せていた。

ではこれらの方針がいかに設計図として表現されたかをみてみ たい。「境内設計図」は社殿周囲およひ境内外周に樹木が密植され ている。樹種の特定はできないが，全体的に針葉樹様の表現で, 社殿裏の池の周囲には広葉樹様の樹木がみられ，数本のカエデと みられる朱色の樹木が確認できる。境内図」と比較するとまばら にあった樹木が集められ，社殿周囲をめぐる通路沿いには芝生の 空間がつくりだされている。この芝生地の確保には，既存よりも 細く計画された通路の効果も大きい。社殿北側の遊就館から相撲 場にかけても樹木が植えられた。池は拡張されて形状が変更され， 社殿を取り囲むように東，南，西へと流れが描かれている。また この図に大鳥居はみあたらず，相撲場は円形で別の用紙に描かれ た図を貼り付けている。これらはいずれも設計方針と符号するも のである。しかし設計前の方針とは異なる点も確認でき，大鳥居 の跡地への小さな鳥居の設置は無く, 池と相撲場の改修が追加さ れている。特に池は流れの新設を伴う大規模なもので, 境内設計 のひとつの主要事項であったことが窺える。

次に「旧馬場設計図」は，直線の参道が設けられ，中央を 8 間 の車道としその両側に歩道 2 間となっている。歩道の脇には針葉 樹様の並木が描かれ，旧馬場外周にはサクラとみられる樹木など が密植されている。旧馬場西端の南北道路は歩道として狭められ， その少し東に新たな南北道路が計画された。銅像は入口北側に移 設され参道の一直線を妨げるものはなく，大鳥居は九段坂上の入 口に描かれている。これらは境内と同じく設計方針と一致する。 ただこちらも設計前の方針とは相違がある。方針中の南北道路を 掘り下げ橋を架ける計画は, 「参道計画図 $\mathrm{c} 」 に$ 確認できたが, 最 終計画として採用されるには至っていない。また費用を取り上げ て新聞紙上を賑わした大鳥居と銅像の移設 ${ }^{30}$ は, 各参道計画図に おける移設か残置かの検討から長岡自身も苦慮したことがわかる。 しかし最終的にはどちらも移設することで計画された。

このように，長岡による靖国神社の森厳さを高めるための改修 設計は，一部道路の掘り下げでは設計前よりも意気を下げた部分 はあるものの，植栽，参道，池流れ，相撲場の改修や，鳥居，銅 像の移設など，設計が進むに従い規模を増していったことが確認 できた。

\section{5. 長岡の設計の実現}

設計案が公表され，すでにこの時に賀茂宮司から「本来ならば 斯んな事はもら以前から出来上つて居なければなら筈だつた」 31) という発言があることから，この改修はあまり軽快には進んで いなかったことが窥える。ここからは設計公表後の工事記録等か ら, 長岡安平の設計がどの程度の時間的経過でどれだけ実現した かを検討したい (時系列は表 - 2 参照)。

\section{(1) 工事記録の整理}

まず図面を伴って改修設計が公表された大正 4（1915）年 2 月 から 4 ケ月後の 6 月 9 日, 拝殿から大鳥居の間の敷石工事が神社 から陸軍省へ申請され，同年 9 月 30 日に竣工している ${ }^{32)}$ 。設計 方針では九段坂上の入口から扯殿までを敷石にするとあったから， 部分的な施工と判断できる。このことから改修は一括して施工さ れず，分割して実施されたことがわかる。この理由が先の申請書 に記載されており，これまで識者の意見を聞きながら検討してき た改修案に対し「格別傾聴スへキ良案モ無之又原案二対シテ八当 局者間二モ多少ノ意義アリ従テ全般二亘儿計画八今俄二難决」が, 「近来凹凸ヨ生シ雨日等二ハ却テ歩行二困難ナルノミナラズ甚ダ 体裁ヨロシカラズ神社ノ威厳二モ相関シ候」とある。この申請書 は賀茂宮司から出されたものであるが，この時点で方針の一致を 見る段階ではなく，支障をきたしている部分からまずは着手した いという趣旨であった。 8 月 27 日の記事には「靖国神社の神苑は 愈全部改造する事に確定せり」 $\left.{ }^{33}\right)$ との記述があり, 靖国神社百年 史によると大正 4 (1915) 年 7 月 5 日に境内と旧馬場を分割して いた南北道路の付け替え工事が起工され，大正 6 (1917) 年 4 月 2 日まで継続されたとある ${ }^{34)}$ 。2 月の設計案公開から 8 月の記事 まで約半年が経過し，この間に設計案について一応の決着がみら れたと考えられるが，設計の内容に大きな違いは確認できない。

大正 4 年 7 月から同 6 年 4 月の間には少なくとも二つの工事記 録が確認できる。工事原議である「旧馬場内改築追加工事（参道 築設）の件」35)によれば，大正 6 年 3 月 2 日に旧馬場内改築追加 工事が靖国神社賀茂宮司によって陸軍省に申請され, 「靖国神社前 参道改修其他工事」として発注された。この工事の内容は参道修 築と灯籠移設を中心としたものであるが，同じ簿冊に境内旧馬場 間の南北道路と旧馬場西側南北道路の付け替えを対象とした「靖 国神社前道路付替其他工事」の設計書が添付されている。また, 同年 1 月 31 日付の新聞には旧馬場西側の南北道路が建設中であ

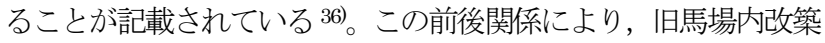
追加工事は靖国神社前道路付替其他工事に追加され実施されたこ とがわかる。この二つの工事のうち道路付け替えは, 靖国神社百 年史のいう 4 月 2 日の直前 3 月 30 日に新聞により竣工が報じら れ 37 ），参道修築は 5 月 18 日に竣工し，陸軍省へ報告された ${ }^{38)}$ 。

以上のことから，靖国神社百年史が示す工事は約 1 年 9 ケ月の 期間に南北道路の付け替えのみ記載されているが，その期間中大 正 4 年には拝殿大鳥居間の敷石と南北道路の付け替え, 大正 6 年 に参道の築設といら三つの工事が実施されたことが明らかである。

\section{(2) 設計の実現と非実現}

これらの工事を，それぞれの設計図書との比較により長岡の設 計案の実現という観点から検討したい。まず拝殿から大鳥居まで の敷石工事については，長岡の案における旧馬場入口から社殿ま でを石敷きの参道とする設計の部分的実現といえる。これは先述 のとおり設計案の決定を待たずに不体裁な部分を先行して施工し たものであり，まずは少しながら工程を進めることができたと評 価できる。次の南北道路付け替えについては，またしても部分的 な施工とはいえ長岡案を踏襲しており, 境内のこの工事で広げら れた箇所には植栽も実施された 39 )

しかし分割されながらも長岡案どおりに工事が続くことはなく, 次の参道築設では大きな変更が確認できる。入口から拝殿まで一 
直線の参道を設けるために主張された銅像の移転は実施されず, 参道は「計画下図」に近い，銅像を残して左右を回り込む形状と なった。参道自体は 8 間の幅員を確保されたものの，その両側に 設けられるはずの歩道 2 間はなく, 舗装は敷石ではなく砂利敷き となっている。また, 話題となっていた大鳥居の移転もなされて いない。一方で南北道路の付け替え工事に伴い, 靖国神社発注の 工事とは別に長岡の計画には無かった旧馬場北側に沿った道路の 拡張が，同じ陸軍省の予算によって実施されたことが窅える 40)。 靖国神社の経費は通常国庫からの年間予算で賄われていた ${ }^{41) か ゙, ~}$ こういった大規模工事には大祭時の臨時交付金や陸軍省からの臨 時支出によっていた ${ }^{42}$ 。神社独自では執行できないこうした資金 事情も, 工事の分割や計画変更の少なからぬ理由として存在して いたと考えられる。

この後, 大正 7 (1918) 年に長岡の計画には無い参集所が竣工 し, 大正 10 (1921) 年には旧馬場入口に第一鳥居が建設された。 第一鳥居の建設は長岡が主張した大鳥居の移転箇所であり，移転 ではないものの, 二つの鳥居を設ける計画は実現したことになる。 しかしこの他は大きな工事記録は残されておらず，境内について は池の改修や流れの創出，相撲場の改修といった計画も実現して いない。大正 12 (1923) 年には関東大震災が発生し靖国神社も 少なからず被害を受けたことから，長岡の設計は第一鳥居の建設 で役割を終えたといえる。長岡の設計が一部を除いて実現しなか った理由は記録になく推測の域を出ないが，先に触れた資金面で の不自由さに比へ，設計案が実現に大きな予算を要するものであ ったことは事実として存在し，また決定をみたとはいえ関係者間 での齟䶜があった経緯もあり，実現に及ばなかった原因をこのよ うな事情に求められるのではないかと考える。

\section{6. まとめ}

本論は長岡安平の靖国神社地設計関連図を中心に，当時の行政 資料，新聞記事等とともに考察し，大正初期に手がけられた靖国 神社地改修の経緯と, 設計者長岡安平および靖国神社宮司賀茂百 樹が目指した神社地像とその実現について明らかにすることを目 的とした。

まずひとつの成果として8枚の長岡が所持した靖国神社関連図 について詳細を明らかにした。これにより新聞記事等にみられる 長岡の設計方針が，いかにして，またどれだけ計画図として反映 されたかを読み解くことができた。しかしその実現については, 工事の分割と変更が重ねられ，実施に至らなかった部分も多く, 原案じおり施工された部分は，わずかに旧馬場の西側に付け替え られた南北道路のみであった。

長岡はこの改修で靖国神社の神聖さを高めることのみを目指し， それは神社の公園化を疑問視する時代性に適い, 靖国神社にとっ ても所期の目的とするものであった。しかし計画の実現には資金 的な制約や，計画に対する関係者の理解の程度差を見出すことが でき,これが計画を変更または停止させた要因として察せられる。 しかしながら，参道は灯籠とともに整えられ，第一鳥居の建設に より, 長岡の計画よりも壮大な二つの鳥居の景観がつくられてい るから, 旧馬場については, 神社の荘厳さを高める長岡と賀茂の 目的は一定程度達したと評価できる。

\section{補注及び参考文献}

1)佐藤俊樹 (2006) : 社の庭一招魂社-靖国神社をめぐる眼差しの政治一: 社會科學研究 57, p.177

2)河村忠伸 (2012) : 近代神社行政における神社境内の公園的性格 : 明治聖德記念学会 紀要復刊 49, 282-283

3)小沢圭次郎 (1893)：公園論, 東京都庁 (1973)：東京市史稿遊園篇 7 : 臨川書店所 収, p.414,419
4)東京朝日新聞 : 大正元 (1912) 年 8 月 7 日朝刊, p.5 5)東京朝日新聞 : 大正 3 (1914) 年1月 10 日朝刊, p.5 6)浦㠃真一 (2014) : 長岡安平の官歴を中心とした経歴区分による設計鄴績の変遷につ いて:ランドスケープ研究Vol.77 No.5, 407-412

7)東京都公園協会みどりの図書館東京グリーンアーカイブスが所蔵する長岡安平遺品 約 800 点からなる史料群。

8)東京市区改正委員会 (1900) : 東京市区改正員会議事録第 2 巻, p.68 9)東京市区改正委員会 (1900) : 東京市区改正員会議事録第 11 巻, p.109 10)東京市区改正員会 (1903) : 東京市区改正法規，p.39

11)アジア歷史資料センター所蔵【件名】総務局靖国神社付属地の公園予定の除外と寸 る件【収録先の名称】明治 36 年乾「武大日記 9 月」(防衛省防衛研究所) Ref.C06083792900

12)靖国神社（1983）：靖国神社百年史資料篇上， p.609

13)浦㖣真一 (2013) : 「公園計画地図」一東京市区改正新設計による公園計画一: 専門 図書館 $262,53-54$

14)前掲: 大正 3 (1914) 年 1 月 10 日朝刊, p.5 15)東京朝日新聞 : 大正 4 (1915) 年 2 月 2 日朝刊, p. 5 16)読売新聞 : 大正 6 (1917) 年 3 月 30 日朝刊, p.5

17)アジア歷史資料センター所蔵【件名】官房靖国神社旧競馬場東側㜳土寄付の件【収 録先の名称】明治 38 年乾「戴大日記 10 月」(防衛省防衛研究所) Ref.C06084075600 18)東京都公文書館蔵【件名】飯田町 1 丁目地先陸軍省用地靖国神社付属地使用願仵可 東京市街鉄道株式会社【収録先の名称】第 1 種 文書類纂・地理 - 第 74 類 - 官有地 第 2 巻 第一部 (土木課)〉【請求番号】 $627 . \mathrm{B} 4.07$ 19)アジア歴史資料センター所藏【件名】旧馬場内改築追加工事 (参道築設) の件【収 録先の名称 大日記乙輯大正 07 年 (防衛省防衛研究所) Ref.C03011035900 20)東京朝日新聞 : 大正 10 (1921) 年6月 8 日夕刊, p.2

21)靖国神社 (1987)：前掲書, p.236

22 )大蔵省印刷局 : 官報第 817 号: 大正 4 (1915) 年4月 26 日, $571-573$

23)前掲: 大正 4 (1915) 年 2 月 2 日朝刊, p.5

24)前掲 : アジア歷史資料センターC06084806300

25)東京朝日新聞 : 明治 44 (1911) 年 12 月 16 日朝刊, p.6

26)前掲: 大正 3 (1914) 年 1 月 10 日朝刊, p.5

27)設計前は, 前掲: 大正 3 (1914) 年 1 月 10 日朝刊, p.5および東京朝日新聞 : 大正 3 (1914) 年 2 月 22 日朝刊, p.5, 同大正 3 (1914) 年 3 月 4 日朝刊, p. 5 より, 設計 公表時は前掲: 大正 4 (1915) 年 2 月 2 日朝刊, p. 5 およひ読売新聞 : 大正 4 (1915) 年 8 月 27 日朝刊, p. 5 より抽出分類し作成。

28)前掲: 大正 4 (1915) 年 8 月 27 日朝刊, p.5

29)前掲: 大正 4 (1915) 年 2 月 2 日朝刊, p.5

30)前掲: 大正 4 (1915) 年 2 月 2 日朝刊, p. 5 および同大正 3 (1914) 年 3 月 4 日朝 刊, p.5, 同大正 4 (1915) 年 2 月 2 日朝刊, p.5 亿大鳥居と銅像の移設のみ金額を挙 げて論じられている。

31)前掲: 大正 4 (1915) 年 2 月 2 日朝刊, p.5 32)アジア歴史資料センター所蔵【件名】靖国神社敷石道己筑の件【収録先の名称】大 日記乙輯大正 06 年 (防衛省防衛研究所) Ref.C03010931200

33)前掲 : 大正 4 (1915) 年 8 月 27 日朝刊, p.5

34)靖国神社 (1987)：前揭書, p.246

35)アジア歴史資料センタ一蔵【件名】旧馬場内改築追加工事（参道築設）の件【収録 先の名称】 大日記乙輯大正 07 年 (防衛省防衛研究所) Ref.C03011035900

36)東京朝日新聞 : 大正 6 (1917) 年1月 31 日朝刊, p.4

$37)$ 読㐊新聞 : 大正 6 (1917) 年 3 月 30 日朝刊, p. 5

38)前掲 : アジア歴史資料センターC03011035900

39)前掲 : 大正 6 (1917) 年 3 月 30 日朝刊, p.5

40)前掲: 大正 6 (1917) 年1月 31 日朝刊, p.4

41)賀茂百樹編（1911）：前掲書, p.75

42)前掲 : アジア歴史資料センターC03010931200 や前掲 : アジア歷史資料センター C03011035900に特别交付金から支出したい旨の記述があり，また前掲:大正6(1917) 年1月 31 日朝刊, p. 4 や読売新聞 : 大正 6 (1917) 年 1 月 31 日朝刊, p.5にも陸軍省 からの支出となる旨記載されている。 